\title{
First Two Cases of Bloom Syndrome in Russia: Lack of Skin Manifestations in a BLM c.1642C>T (p.Q548X) Homozygote as a Likely Cause of Underdiagnosis
}

\author{
Evgeny N. Suspitsin ${ }^{a, b}$ Farida I. Sibgatullina ${ }^{f}$ Lydia V. Lyazinac $^{c}$ \\ Evgeny N. Imyanitova, b, d, e \\ ${ }^{a}$ St. Petersburg State Pediatric Medical University, ${ }^{b}$ N.N. Petrov Institute of Oncology, ${ }^{c}$ St. Petersburg Center \\ of Medical Genetics, d I.I. Mechnikov North-Western Medical University, and 'St. Petersburg State University, \\ St. Petersburg, and ${ }^{f}$ Children Clinical Hospital of the Republic of Tatarstan, Kazan, Russia
}

\section{Established Facts}

- $0.2-0.6 \%$ individuals of Slavic descent carry an inactivating mutation in the BLM gene.

- Despite the high frequency of the BLM c.1642C>T (p.Q548X) allele, no Slavic patients with Bloom syndrome (BS) have been described so far.

\section{Novel Insights}

- Here, we present the first 2 cases of BS in Russia; both patients were observed by genetic counselors but remained without correct diagnosis for years.

- One of the affected children lacked a key feature of BS, i.e., increased skin sensitivity to ultraviolet irradiation.

- Slavic patients with short stature, skin photosensitivity, paucity of subcutaneous fat, recurrent infections, cancer at young age or other features of BS need to be screened for the BLM c.1642C>T (p.Q548X) allele.

\section{Key Words}

Bloom syndrome · Immune deficiency - Short stature .

Photosensitivity $\cdot$ Recurrent mutations

\section{Abstract}

Bloom syndrome (BS) is an exceptionally rare hereditary disease. Typical manifestations of BS usually include growth deficiency, a characteristic facial appearance, skin hypersensitivity to ultraviolet irradiation, and a strong predisposition to early-onset cancers. We have previously described a recurrent BLM c.1642C >T (p.Q548X) mutation, which is present in heterozygous state in $0.2-0.6 \%$ of individuals of Slavic origin. Despite the high occurrence of this founder allele, BS has not yet been described in patients of Slavic ethnicity. Here, we present 2 cases of BS, which were missed by standard genetic counseling and were eventually identified entirely due to chance. Our patients show

\section{KARGER}

(C) 2017 S. Karger AG, Basel

E-Mail karger@karger.com

www.karger.com/msy
Evgeny N. Imyanitov, MD, PhD

Laboratory of Molecular Oncology, N.N. Petrov Institute of Oncology Pesochny 2

RU-197758 St. Petersburg (Russia)

E-Mail evgeny@imyanitov.spb.ru 
the need for further investigations to confirm whether the atypical appearance of BS is indeed characteristic for biallelic carriers of the c.1642C > T (p.Q548X) allele and whether the absence of skin manifestations contributes to the underdiagnosis of the disease in Russia. Therefore, we suggest that all Slavic patients with only one single clinical feature of BS are to be screened for this allele and subjected to further analysis wherever appropriate. In addition to identifying new BS patients, this effort will help to clarify the frequency of "atypical BS" with incomplete phenotypic manifestations.

(c) 2017 S. Karger AG, Basel

Bloom syndrome (BS, OMIM 210900) is an orphan disorder, which was described by the New York dermatologist David Bloom in 1954 [Bloom, 1954] and is characterized by varying disease manifestations. Growth deficiency is the most constant clinical feature of BS patients. Other typical BS signs include hypersensitivity of the skin to ultraviolet exposure, a characteristic facial appearance, recurrent infections, and a strong predisposition to earlyonset malignant diseases. BS is caused by biallelic inactivation of the $B L M$ gene, which encodes a RecQ subfamily DNA helicase and is responsible for the maintenance of genomic stability. Less than $300 \mathrm{BS}$ patients have been described up to now, with about a quarter of them carrying the biallelic Ashkenazi Jewish founder mutation BLM c.2207-2212delATCTGAinsTAGATTC (BLM $\left.{ }^{\text {Ash }}\right)$. Approximately $1 \%$ of Ashkenazi Jews are heterozygous for the $B L M^{\text {Ash }}$ allele; therefore, the appropriate genetic screening of this population is warranted (see the Bloom Syndrome Registry; http://weill.cornell.edu/bsr/) [Roa et al., 1999; German et al., 2007; Arora et al., 2014; Cunniff et al., 2017].

While biallelic defects in DNA repair genes often cause severe multiorgan genetic syndromes, heterozygous carriers of these mutations are clinically healthy but characterized by increased cancer predisposition [Gruber et al., 2002; Kleibl and Kristensen, 2016]. We recently analyzed the $B L M$ gene as a candidate for hereditary breast cancer (BC), and revealed its association with $\mathrm{BC}$ risk [Sokolenko et al., 2012]. The BC-predisposing role of $B L M$ was later confirmed by exome sequencing and case-control studies [Thompson et al., 2012; Prokofyeva et al., 2013], although a negative report has been published as well [Anisimenko et al., 2014]. Interestingly, these studies identified a founder $B L M$ mutation c.1642C > T (p.Q548X), with the frequency of its heterozygous carriers in Slavic populations usually falling with-

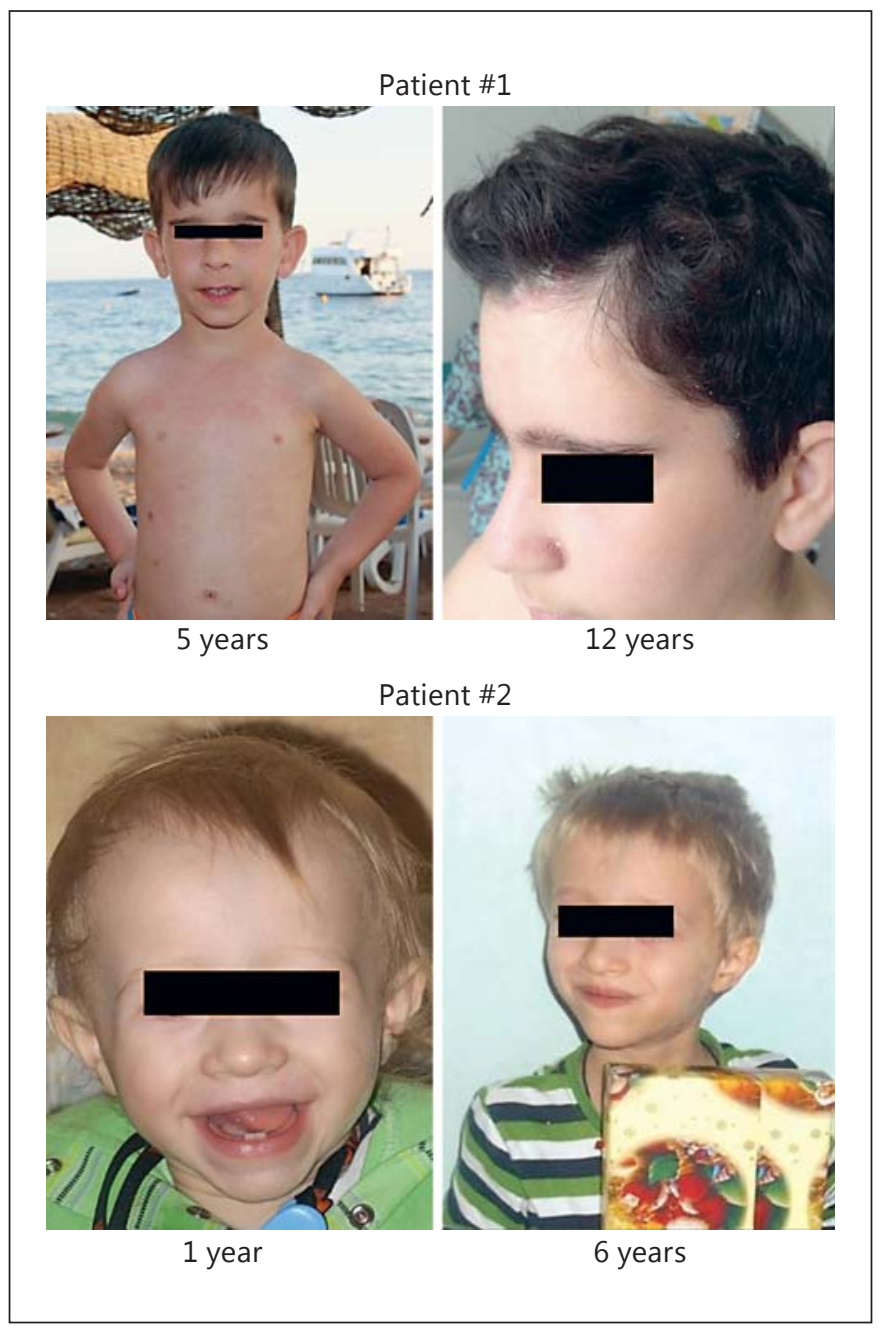

Fig. 1. The appearance of patients with BS at different ages.

in the range of $0.2-0.6 \%$ (Table 1 ). If we assume that the total number of Slavs in the world is close to 300 million people, with almost a half of them residing in Russia, one would expect that up to $300-2,700$ people of Slavic origin may currently suffer from BS. Perhaps, the actual number of prevalent BS cases in Slavic countries is somewhat lower, given a shortened life expectancy in BS patients [German et al., 2007; Arora et al., 2014; Cunniff et al., 2017]. However, it is still appropriate to expect an increased occurrence of BS in this part of the world. After the initial publication on high frequency of the $B L M$ c.1642C>T (p.Q548X) mutation [Sokolenko et al., 2012], we contacted all major genetic centers operating in Russia by telephone, but no patients with BS were identified upon this effort. 
Table 1. Frequency of $B L M$ c.1642C $>T$ (p.Q548X) heterozygotes among subjects of Slavic origin

\begin{tabular}{lllr}
\hline Study & Location & Subjects & Frequency \\
\hline Sokolenko et al., 2012 & Russia, St. Petersburg & cancer-free & $5 / 2,184(0.23 \%)$ \\
Prokofyeva et al., 2013 & Belarus & cancer-free females & $2 / 1,235(0.16 \%)$ \\
Antczak et al., 2013 & Poland & cancer-free males & $15 / 2,604(0.58 \%)$ \\
Anisimenko et al., 2014 & Russia, Novosibirsk & & $35 / 7,920(0.44 \%)$ \\
Bogdanova et al., 2015 & Russia, Ufa & cancer-free & $0 / 604(0.00 \%)$ \\
\hline
\end{tabular}

Table 2. Clinical description of BS patients

\begin{tabular}{|c|c|c|c|c|c|c|c|c|c|c|c|}
\hline $\begin{array}{l}\text { Patient ID, } \\
\text { gender, age } \\
\text { at diagnosis }\end{array}$ & $\begin{array}{l}B L M \\
\text { germline } \\
\text { mutation }\end{array}$ & $\begin{array}{l}\text { History } \\
\text { of IUGR }\end{array}$ & $\begin{array}{l}\text { Parameters } \\
\text { at birth }\end{array}$ & $\begin{array}{l}\text { History } \\
\text { of feeding } \\
\text { difficulties }\end{array}$ & Height & $\begin{array}{l}\text { Facial } \\
\text { appearance }\end{array}$ & Skin lesions & Infections & $\begin{array}{l}\text { Immune } \\
\text { status }\end{array}$ & Cancer & $\begin{array}{l}\text { Other clinical } \\
\text { features }\end{array}$ \\
\hline $\begin{array}{l}\text { Patient } 1 \\
\text { Male, } \\
12 \text { years }\end{array}$ & $\begin{array}{l}\text { c. } 1642 \mathrm{C}>\mathrm{T} \\
\text { (p.Q548X)/ } \\
\text { c.2512C>T } \\
\text { (p.Q838X) }\end{array}$ & yes & $\begin{array}{l}\text { height: } 44 \mathrm{~cm} \text {; } \\
\text { weight: } 1,765 \mathrm{~g} \text {; } \\
\text { OFC: } 28 \mathrm{~cm} \text {; } \\
\text { Apgar score: } 7-8\end{array}$ & yes & $\begin{array}{l}138 \mathrm{~cm} \\
(-1.6 \mathrm{SD})\end{array}$ & $\begin{array}{l}\text { long face, } \\
\text { prominent } \\
\text { nose and } \\
\text { ears }\end{array}$ & $\begin{array}{l}\text { multiple café- } \\
\text { au-lait spots; } \\
\text { sun-induced } \\
\text { erythema around } \\
\text { nose; facial } \\
\text { seborrheic } \\
\text { dermatitis instead } \\
\text { of erythema since } \\
\text { the age of } 9 \text { years }\end{array}$ & $\begin{array}{l}\text { recurrent } \\
\text { respiratory } \\
\text { infections; } \\
2 \text { episodes of } \\
\text { pneumonia } \\
\text { (at the age of } \\
10 \text { and } 12 \\
\text { years); } \\
\text { chronic rhinitis }\end{array}$ & low IgM & - & $\begin{array}{l}\text { sparseness of } \\
\text { subcutaneous fat } \\
\text { before puberty, but } \\
\text { premature } \\
\text { pubescence } \\
\text { accompanied by } \\
\text { excessive weight } \\
\text { gain }\end{array}$ \\
\hline $\begin{array}{l}\text { Patient } 2 \\
\text { Male, } \\
6 \text { years }\end{array}$ & $\begin{array}{l}\text { c. } 1642 \mathrm{C}>\mathrm{T} \\
\text { (p.Q548X)/ } \\
\text { c. } 1642 \mathrm{C}>\mathrm{T} \\
\text { (p.Q548X) }\end{array}$ & yes & $\begin{array}{l}\text { height: } 50 \mathrm{~cm} \text {; } \\
\text { weight: } 2,850 \mathrm{~g} \text {; } \\
\text { OFC: } 33.5 \mathrm{~cm} \text {; } \\
\text { Apgar score } 7-8\end{array}$ & yes & $\begin{array}{l}105 \mathrm{~cm} \\
(-2.1 \mathrm{SD})\end{array}$ & $\begin{array}{l}\text { long face, } \\
\text { prominent } \\
\text { nose }\end{array}$ & none & $\begin{array}{l}\text { pneumonia at } \\
\text { the first year of } \\
\text { life; recurrent } \\
\text { respiratory } \\
\text { infections; } \\
\text { enterocolitis } \\
\text { and pneumonia } \\
\text { during cancer } \\
\text { chemotherapy }\end{array}$ & $\begin{array}{l}\text { low IgA, } \\
\text { IgM, IgG }\end{array}$ & $\begin{array}{l}\text { medullo- } \\
\text { blastoma } \\
\text { at the age } \\
\text { of } 4 \text { years }\end{array}$ & $\begin{array}{l}\text { sparseness of } \\
\text { subcutaneous fat; } \\
\text { chronic diarrhea; } \\
\text { lactose intolerance }\end{array}$ \\
\hline
\end{tabular}

Ig, immunoglobulin; IUGR, intrauterine growth retardation; OFC, occipitofrontal circumference. Patient 1 is from Kazan and patient 2 from St. Petersburg.

\section{Case Report}

Here, we present the first 2 cases of BS in Russia, which were revealed entirely due to chance. The first child, a boy, was born from parents residing in the Republic of Tatarstan, Russia; his mother had mixed Russian-Tatar roots, while his father was ethnic Russian. The boy was observed regularly in an endocrinology center because of short stature. Despite receiving genetic counseling, BS was not suspected, but the diagnosis of Cornelia de Lange syndrome was assigned. At the age of 5 years, he accompanied his brother to an immunologist simply because he could not be left at home alone. The doctor took notice of his BS-like facial appearance, collected relevant clinical information, and eventually suggested the diagnosis of BS (Fig. 1; Table 2). Genetic testing was initiated 7 years later, at the age of 12 years, and he was found to be a compound heterozygote for c.1642C >T (p.Q548X) and c. $2512 \mathrm{C}>\mathrm{T}$ (p.Q838X) alleles. BLM c.2512C $>\mathrm{T}$ (p.Q838X) is a novel mutation affecting the DEAH helicase domain. Given that the mother carries the Slavic c.1642C>T (p.Q548X) allele, the c.2512C $>\mathrm{T}$ (p.Q838X) substitution was almost certainly transmitted to the child by his father; we were unable to confirm this fact because he died in an accident. We did not find the c.2512C $>\mathrm{T}$ (p.Q838X) allele among 575 Russian healthy residents of St. Petersburg; considering that the father of the patient originated from a family residing in Tatarstan, the population frequency of this mutation deserves to be further examined within this geographic region.

The second child, born from unrelated Russian parents originating from distinct regions of Russia (Arkhangelsk and Krasnodar), was monitored regularly by immunologists, clinical geneticists, and endocrinologists because of growth deficiency, recurrent infections, and some other health problems (Fig. 1; Table 2). Strikingly, at least 2 of the clinical geneticists involved in counseling were aware of a frequent occurrence of $B L M$ founder mutations in Russia, but they still did not consider BS as a possible diagnosis, probably because the child's mother did not report any evidence for increased photosensitivity. Blood DNA from the child was used for next-generation sequencing of 302 immune-related genes in the frame of a research project dedicated to primary immunodeficiencies, and a homozygous Slavic BLM c.1642C>T (p.Q548X) mutation was revealed. The boy died at the age of 6 years due to progression of desmoplastic medulloblastoma. 


\section{Discussion}

A mistaken and/or delayed diagnosis is a common problem for the most of orphan diseases [EURORDISCARE 2: Survey of the delay of diagnosis; http://www. eurordis.org/sites/default/files/publications/Fact_Sheet_ Eurordiscare2.pdf]. We are not aware of other cases of BS in countries with predominantly Slavic population [German et al., 2007; see Bloom's Syndrome Registry], and these BS patients are likely to be missed due to lack of vigilance among medical professionals. The diagnosis of BS may be complicated in some circumstances, given that the only relatively constant features of BS are a short stature and a sun-induced erythema, while the appearance of other disease characteristics may vary [German et al., 2007]. Furthermore, the majority of BS patients described in the literature are carriers of the $B L M^{\text {Ash }}$ allele [German et al., 2007; Arora et al., 2014; Cunniff et al., 2017]. It remains to be investigated whether the location of the inactivating mutation within the $B L M$ gene influences the disease phenotype. For example, the second child described in this study presented with atypical appearance of BS, i.e., he lacked facial sun-induced erythema (Table 2); it is unclear, whether the absence of skin symptoms is related to low sun exposure, phenotypic effect of BLM c.1642C >T (Q548X) mutation, or other factors. If this "atypical BS", being characterized by the lack of skin manifestations, is indeed common for biallelic carriers of the BLMc.1642C $>\mathrm{T}$ (p.Q548X) mutation, this could plausibly explain the BS underdiagnosis in Slavic countries. It is also important to acknowledge that the definite diagnosis of BS in the described cases was established purely by the fact of a bial- lelic inactivated mutation in the BLM gene; unfortunately, the sister chromatic exchange assay, which is a standard tool for BS diagnosis, was not available to these patients.

Given that testing for recurrent BLM c.1642C $>\mathrm{T}$ (Q548X) mutation is very simple and inexpensive, we suggest that all Slavic patients with only a single feature of BS (short stature, skin photosensitivity, paucity of subcutaneous fat, recurrent infections, cancer at young age, etc.) are to be screened for this recurrent allele. The mutation spectrum of the BLM gene is not limited to BLM c.1642C $>$ T (Q548X) even in Slavic populations; therefore, individuals with a heterozygous BLM c.1642C $>\mathrm{T}$ (Q548X) genotype and/or combination of BS clinical features should always be considered for full-length $B L M$ analysis. This effort will help to identify new BS patients as well as to clarify the frequency of "atypical BS" with incomplete phenotypic manifestations.

\section{Acknowledgment}

This work was supported by the Russian Scientific Fund (grant 15-15-00079).

\section{Statement of Ethics}

The authors have no ethical conflicts to disclose.

\section{Disclosure Statement}

The authors have no conflicts of interest to declare.

\section{References}

Anisimenko MS, Kozyakov AE, Paul GA, Kovalenko SP: The frequency of the BLM p.Q548X (c.1642C $>\mathrm{T}$ ) mutation in breast cancer patients from Russia is no higher than in the general population. Breast Cancer Res Treat 148:689-690 (2014).

Antczak A, Kluźniak W, Wokołorczyk D, Kashyap A, Jakubowska A, et al: A common nonsense mutation of the $B L M$ gene and prostate cancer risk and survival. Gene 532: 173-176 (2013).

Arora H, Chacon AH, Choudhary S, McLeod MP, Meshkov L, et al: Bloom syndrome. Int J Dermatol 53:798-802 (2014).

Bloom D: Congenital telangiectatic erythema resembling lupus erythematosus in dwarfs; probably a syndrome entity. AMA Am J Dis Child 88:754-758 (1954).

Bogdanova N, Togo AV, Ratajska M, Kluźniak W, Takhirova Z, et al: Prevalence of the BLM nonsense mutation, p.Q548X, in ovarian cancer patients from Central and Eastern Europe. Fam Cancer 14:145-149 (2015).

Cunniff C, Bassetti JA, Ellis NA: Bloom's syndrome: clinical spectrum, molecular pathogenesis, and cancer predisposition. Mol Syndromol 8:4-23 (2017).

German J, Sanz MM, Ciocci S, Ye TZ, Ellis NA: Syndrome-causing mutations of the BLM gene in persons in the Bloom's Syndrome Registry. Hum Mutat 28:743-753 (2007).

Gruber SB, Ellis NA, Scott KK, Almog R, Kolachana $\mathrm{P}$, et al: $B L M$ heterozygosity and the risk of colorectal cancer. Science 297:2013 (2002).

Kleibl Z, Kristensen VN: Women at high risk of breast cancer: molecular characteristics, clinical presentation and management. Breast 28: 136-144 (2016).

Prokofyeva D, Bogdanova N, Dubrowinskaja N, Bermisheva M, Takhirova Z, et al: Nonsense mutation p.Q548X in BLM, the gene mutated in Bloom's syndrome, is associated with breast cancer in Slavic populations. Breast Cancer Res Treat 137:533-539 (2013).

Roa BB, Savino CV, Richards CS: Ashkenazi Jewish population frequency of the Bloom syndrome gene 2281 delta 6ins7 mutation. Genet Test 3:219-221 (1999).

Sokolenko AP, Iyevleva AG, Preobrazhenskaya EV, Mitiushkina NV, Abysheva SN, et al: High prevalence and breast cancer predisposing role of the BLM c.1642 C>T (Q548X) mutation in Russia. Int J Cancer 130:2867-2873 (2012).

Thompson ER, Doyle MA, Ryland GL, Rowley SM, Choong DY, et al: Exome sequencing identifies rare deleterious mutations in DNA repair genes FANCC and BLM as potential breast cancer susceptibility alleles. PLoS Genet 8:e1002894 (2012). 